\title{
Regional water and environmental analysis of the Ural Federal District
}

\author{
A.I. Semyachkov, V.A. Pochechun, and K.A. Semyachkov \\ Ural State Mining University, 620144, Kuibyshev Str., 30, Ekaterinburg, Russia
}

\begin{abstract}
The article explains the need to diagnose the man-made impact on water resources as a priority task to ensure the environmental safety of the territory in order to develop a sound regional environmental policy in relation to the sustainable and environmentally safe use of water resources. The diagnostic results of the water and environmental situation in the Ural Federal District are provided.
\end{abstract}

\section{Introduction}

Development of the sound regional environmental policy, effective state regulation of activities ensuring the achievement of environmentally sound sustainable development [1] require the comparative diagnosis of condition and assessment of the man-made impact on the environment, appropriate assessment of the environmental situation by the natural conditions and the environmental safety of the regions. These factors are presented in this article for the conditions of the Ural region in the context of water protection activities.

\section{Materials and methods}

This paper is based on the results of analytical studies considering the use of official statistics, references, and water resource monitoring data.

\section{Results and discussion}

Among the constituent entities of the Russian Federation, over the past ten years (2008-2017) the Ural Federal District ranks fourth in terms of environmental situation. The polluted effluent discharge in the entire Ural Federal District over this period increased by $19.5 \%$ and amounted to 2,231 million $\mathrm{m} 3$ in 2017 (Table 1). A sharp increase in the total discharge of polluted effluents in the Ural Federal District has been observed since 2014, mainly due to an increase in this indicator in the Khanty-Mansiisk Autonomous District - Yugra (Fig. 1) [4, 6-11].

The share of polluted effluents in the total volume of wastewater discharged into the surface water bodies by the region of the Urals Federal District in 2017 is presented in Figure 2. The insufficiently treated wastewater prevails in the structure of polluted effluents in almost all regions. The share of the Ural Federal District territories in the polluted effluent discharge has changed significantly since 2008. The Khanty-Mansiisk Autonomous District 
- Yugra makes the largest specific contribution to the increase in polluted effluent discharge due to a sharp decrease in 2014 of discharge of the effluents treated to standard quality and transfer of a part of the discharged effluents to the status of polluted effluents (insufficiently treated). It relates to the fact that several large water consumers have not reached the permissible discharge standards, as well as an entire sharp increase in the polluted effluent discharge (by almost 7 times) in 2014. The changes in quality of the discharged effluents and transfer of water treated to standard quality to the polluted effluent status, as well as an increase in oil production by the individual oil companies of the Khanty-Mansiisk Autonomous District - Yugra have also entailed an increase in the impact on water bodies [4, 6-11].

Table 1. Polluted effluent discharge, $\mathrm{mln}^{3}$

\begin{tabular}{|l|c|c|c|c|c|c|c|c|c|c|}
\hline \multicolumn{1}{|c|}{ Regions } & 2008 & 2009 & 2010 & 2011 & 2012 & 2013 & 2014 & 2015 & 2016 & 2017 \\
\hline $\begin{array}{l}\text { Ural Federal } \\
\text { District }\end{array}$ & 1867 & 1702 & 1860 & 1834 & 1665 & 1624 & 2041 & 1996 & 2295 & 2231 \\
\hline Kurgan region & 54 & 52 & 50 & 46 & 43 & 40 & 39 & 38 & 38 & 36 \\
\hline Sverdlovsk region & 873 & 780 & 763 & 770 & 712 & 687 & 667 & 660 & 616 & 586 \\
\hline $\begin{array}{l}\text { Khanty-Mansiisk } \\
\text { Autonomous } \\
\text { District }\end{array}$ & 42 & 46 & 55 & 39 & 41 & 78 & 545 & 463 & 812 & 775 \\
\hline $\begin{array}{l}\text { Yamalo-Nenets } \\
\text { Autonomous } \\
\text { District }\end{array}$ & 48 & 33 & 44 & 39 & 34 & 25 & 22 & 23 & 30 & 31 \\
\hline Tyumen region & 100 & 100 & 103 & 105 & 92 & 82 & 89 & 87 & 86 & 84 \\
\hline $\begin{array}{l}\text { Chelyabinsk } \\
\text { region }\end{array}$ & 750 & 691 & 845 & 836 & 744 & 712 & 679 & 725 & 713 & 719 \\
\hline
\end{tabular}

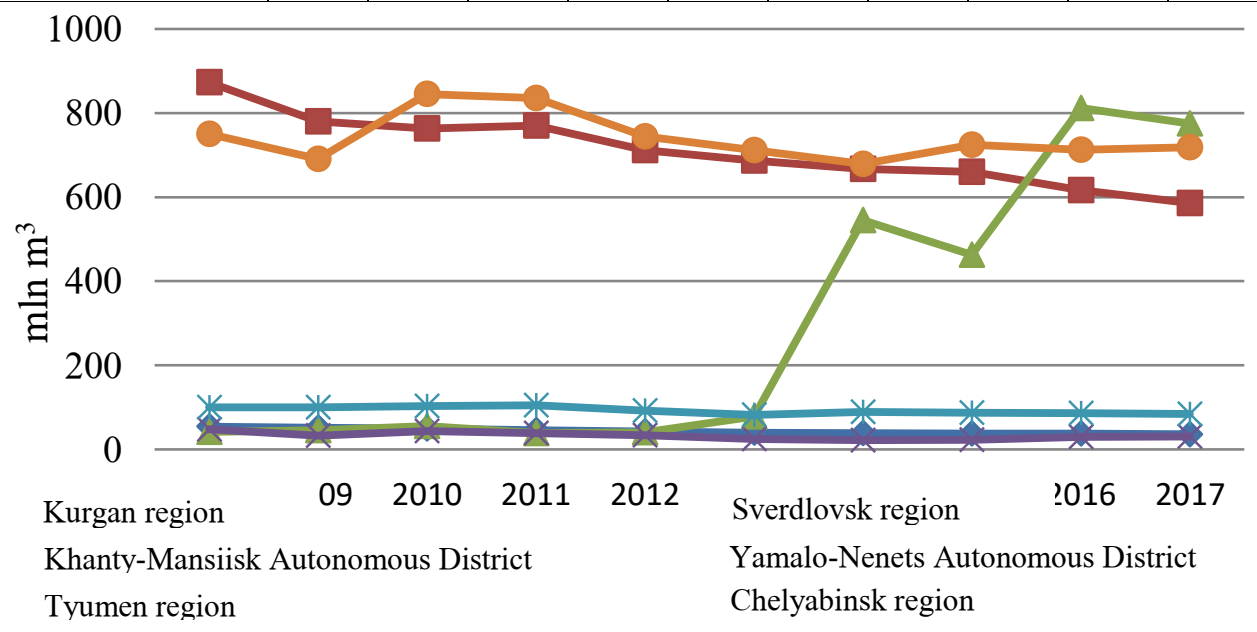

Fig.1. Dynamics of the polluted effluents in the Ural Federal District 


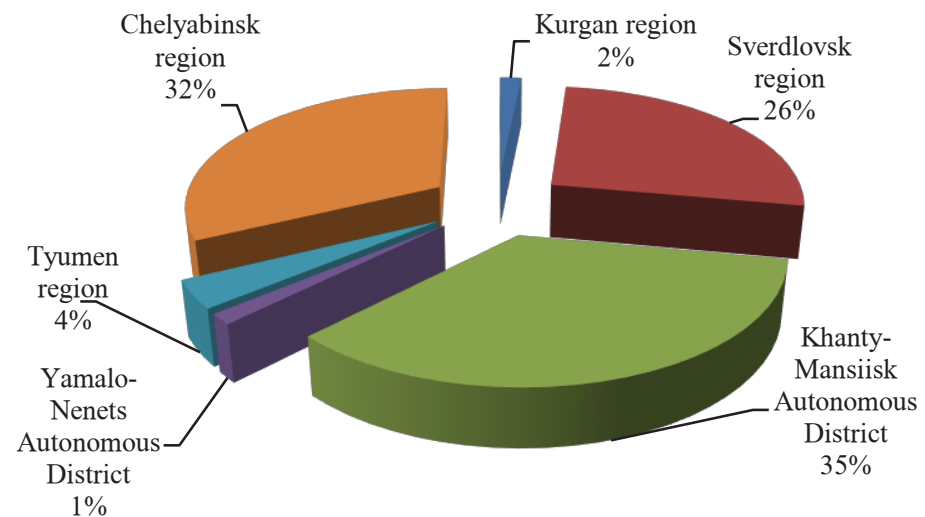

Fig.2. Share of territories of the Ural Federal District in the volume of polluted effluent discharge in 2017

In order to conduct studies of the environmental and economic processes characterizing the environmental pollution trends, we used the index of polluted effluent specific discharge into the surface water bodies. This index is determined as the ratio of the polluted effluent discharge index to the industrial production index [3] and specifies changes in the "environmental friendliness" of the production economic activity [2].

Table 2 shows the calculation results relating to the specific polluted effluent discharge index by the regions of the Urals Federal District over a ten-year period (2008 is accepted as the reference year). Figure 3 demonstrates a graphical change in the indices for the analyzed period.

Table 2. Specific polluted effluent discharge index (decimal quantities)

\begin{tabular}{|l|c|c|c|c|c|c|c|c|c|c|}
\hline Regions & 2008 & 2009 & 2010 & 2011 & 2012 & 2013 & 2014 & 2015 & 2016 & 2017 \\
\hline $\begin{array}{l}\text { Ural Federal } \\
\text { District }\end{array}$ & 1 & 0.93 & 1.1 & 0.94 & 0.88 & 0.86 & 1.09 & 1.09 & 1.22 & 1.2 \\
\hline Kurgan region & 1 & 1.25 & 0.82 & 0.77 & 0.73 & 0.74 & 0.74 & 0.69 & 0.69 & 0.64 \\
\hline $\begin{array}{l}\text { Sverdlovsk } \\
\text { region }\end{array}$ & 1 & 1.09 & 0.74 & 0.83 & 0.75 & 0.77 & 0.75 & 0.79 & 0.66 & 0.69 \\
\hline $\begin{array}{l}\text { Khanty-Mansiisk } \\
\text { Autonomous } \\
\text { District }\end{array}$ & 1 & 1.12 & 1.34 & 0.95 & 1 & 1.89 & 13.23 & 11.3 & 19.2 & 18.89 \\
\hline $\begin{array}{l}\text { Yamalo-Nenets } \\
\text { Autonomous } \\
\text { District }\end{array}$ & 1 & 0.77 & 0.88 & 0.79 & 0.72 & 0.49 & 0.46 & 0.46 & 0.58 & 0.64 \\
\hline Tyumen region & 1 & 1.04 & 1.03 & 0.99 & 0.93 & 0.82 & 0.9 & 0.87 & 0.84 & 0.85 \\
\hline $\begin{array}{l}\text { Chelyabinsk } \\
\text { region }\end{array}$ & 1 & 1.15 & 1.02 & 1.11 & 0.98 & 0.96 & 0.88 & 0.99 & 0.99 & 0.9 \\
\hline
\end{tabular}




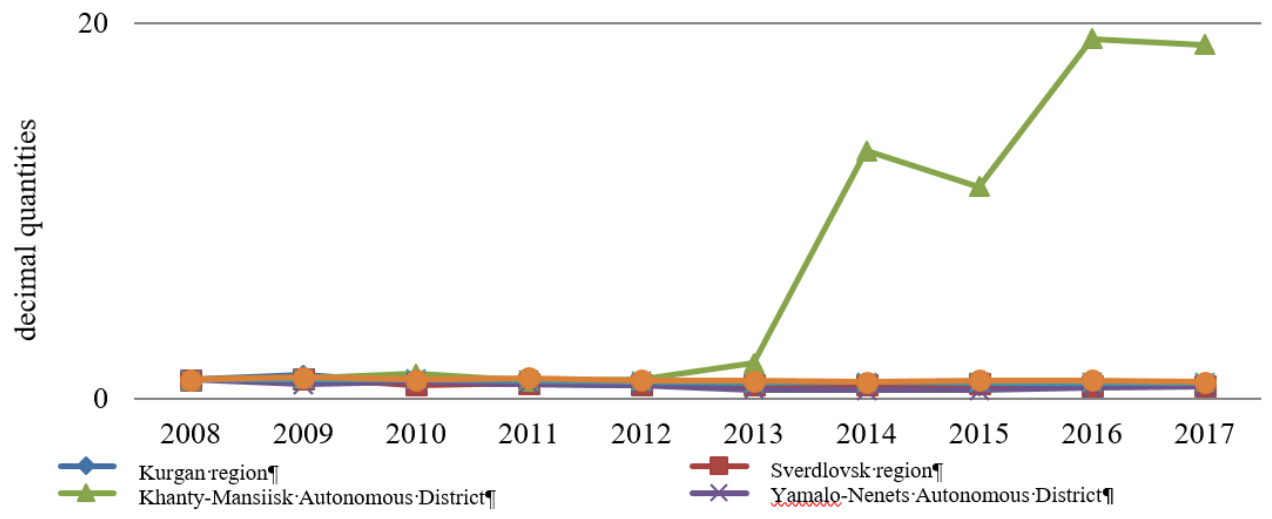

Fig.3. Dynamic pattern of the specific polluted effluent discharge indices by the regions of the Ural Federal District

An analysis of the indices presented above indicates that the regions of the Urals Federal District (except for the Khanty-Mansiisk Autonomous District - Yugra) show a positive trend of decrease in the specific polluted effluent discharge index. The exception is the territory of the Khanty-Mansiisk Autonomous District - Yugra, where the converse situation has been observed since 2013.

What are the enterprise effluents and what impact do they have on the water body? Thus, a chemical analysis of 154 water samples taken by us from 7 sites of the Seversky water storage reservoir, located in the Polevsky district of the Sverdlovsk region and being under the intense influence from the effluents of mining and metallurgical enterprises in this region, showed excesses over the standard values for the following components: sulfate ion - 1.16 MAC, copper - 100 MAC, zinc - 5 MAC, manganese - 1.9 MAC. In 76 samples taken from 3 effluents entering the Seversky water storage reservoir, the excess of polluting elements over the standard values is as follows: for copper - $2140 \mathrm{MAC}$, zinc - $4604 \mathrm{MAC}$.

The data obtained allow us to conclude that the Seversky water storage reservoir is actually a technogenic reservoir, the water quality in which is based on the technogenic localized effluents.

\section{Conclusions}

The analysis of the water protection activity indicators for the conditions of the Ural Federal District over the past ten years showed that the entire polluted effluent discharge during the period from 2008 to 2017 was decreased. However, the availability of the effluent treatment facilities in the regions of the Ural Federal District has remained almost unchanged for ten years, as evidenced by the environmental condition of some water bodies.

\section{References}

1. V.G. Ignatov, A.V. Kokin, Public and municipal administration: Proceedings of the North-Caucasus Academy of Public Administration, 2, 17-27 (2000)

2. N.V. Khilchenko, A.A. Litvinova, K.N. Barduk, O.S. Pashnina, P.I. Tulutov, Environmental safety diagnostics of economic activity in the regions of the Ural Federal District, 68 (Yekaterinburg: Institute of Economics, Ural Branch of the Russian Academy of Sciences, 2004) 
3. Industrial production indices

URL:http://www.gks.ru/wps/wcm/connect/rosstat_main/rosstat/ru/statistics/enterprise/ industrial

4. Report on the environmental situation in the Khanty-Mansiisk Autonomous District Yugra in 2008-2017 URL:https://prirodnadzor.admhmao.ru/doklady-i-otchyety/

5. Water cadaster of the Russian Federation. Surface and ground water resources, its use and quality. Annual publication, 164 (Moscow: RPTs Ofort LLC, 2017)

6. Report on the environmental situation in the Tyumen region in 2008, 2009-2017 URL: https://admtyumen.ru/ogv_ru/about/ecology/eco_monitoring/more.htm?id=11552245 @ecmsArticle

7. Joint report on the environmental conditions in the Chelyabinsk region in 2008, 20092017

8. National report on the environmental conditions and protection in the Sverdlovsk region in 2008, 2009-2017

9. National report on the natural resources and environmental protection in the Kurgan region in 2008, 2009-2017

10. Report on the environmental situation in the Yamalo-Nenets Autonomous District in 2008, 2009-2017

11. Regions of Russia. Socio-economic indicators by years 